\title{
Menggali Nilai-Nilai Pelestarian Lingkungan Geografis Pada Beberapa Desain Seni Pewayangan Bali
}

\section{Gede Putu Eka Suryana dan I Gede Made Yudi Antara}

Masuk: 09042019 / Diterima: 18062019 / Dipublikasi: 30062019

(c) 2019 Fakultas Hukum dan IImu Sosial UNDIKSHA dan IGI

\begin{abstract}
Art products produced by inspired artists are not far from the geographical environment. The values of local wisdom, some of which originate from cultural heritage obtained from generation to generation, can be used as relevant guidelines to be applied at this time. The purpose of this research is to explore the values in terms of art design concerning the description of the geographical environment and knowing mutual relations, that in Balinese puppet art there is a message of efforts in environmental preservation. The research designed consists of collecting data related to data on art products in Balinese wayang, which are then analyzed by hermeneutic methods. The results of the analysis obtained are in one of the puppet stories, Adi Parwa, which tells the story of the search for Tirta Amerta, capturing the current concept that we know as Padmasana. Padmasana, as a religious building by Hindus using hermeneutic analysis methods, is abstracted back in functionality. The idea of Padmasana in real terms that we find every day helps form a new concept related to water storage.
\end{abstract}

Key words Environmental Conservation Value; Geographical Environment; Puppet Art Design

\begin{abstract}
Abstrak Produk seni yang dihasilkan oleh seniman terinspirasi tidak jauh dari lingkungan geografis. Nilai-nilai kearifan lokal yang beberapa berasal dari warisan budaya yang diperoleh secara turun temurun dapat dijadikan pedoman yang relevan untuk diterapkan saat ini. Tujuan dari penelitian ini adalah menggali nilai-nilai dari segi desain seni dalam hubungannya dengan pendeskripsian lingkungan geografis dan mengetahui hubungan timbal balik, bahwa dalam karya seni pewayangan Bali terdapat pesan upaya dalam pelestarian lingkungan. Metodologi yang dirancang terdiri dari pengumpulan data terkait data produk seni dalam pewayangan Bali yang kemudian dianalisis dengan metode hermeneutik. Hasil analisis yang diperoleh adalah dalam salah satu parwa cerita pewayangan yakni Adi Parwa yang mengisahkan adanya pencarian tirta amerta, memperoleh konsep saat ini yang kita kenal sebagai Padmasana. Padmasana sebagai bangunan religius oleh umat Hindu menggunakan metode analisis hermeneutic diabstraksi kembali secara fungsionalitas. Konsep padmasana secara riil yang kita temukan sehari-hari, membantu membentuk konsep baru terkait dengan cadangan air.
\end{abstract}

Kata kunci : Nilai Pelestarian Lingkungan; Lingkungan Geografis; Desain Seni Wayang

\section{Pendahuluan}

Perkembangan ilmu pengetahuan dan teknologi berasal dari berbagai titik tolak inspirasi dalam kemajuannya. Inspirasi dapat berasal dari apa yang telah kita miliki, diantaranya adalah warisan budaya, yang di dalamnya sarat nilai-nilai yang dapat diterapkan dalam berbagai bidang kehidupan. Lingkungan merupakan tempat yang menyediakan berbagai sumberdaya sekaligus permasalahan

\footnotetext{
I Gede Putu Eka Suryana dan I Gede Made Yudi Antara STMIK STIKOM, Denpasar

gdekasuryana@gmail.com
}

dalam menghadapi pembangunan yang berkelanjutan. Berbagai cara telah diupayakan oleh ilmuwan terkait dengan upaya pelestarian lingkungan, khususnya lingkungan geografis. Isu-isu terkait permasalahan lingkungan global pun sebenarnya sejak lama. Namun penurunan kondisi lingkungan terjadi di berbagai tempat di beberapa belahan dunia. Perspektif global mengajarkan kita berpikir secara global dan bertindak secara lokal. Pelajaran yang dapat kita petik dari hal tersebut adalah nilai-nilai kearifan lokal yang beberapa berasal dari warisan budaya yang diperoleh secara turun temurun dapat dijadikan bahan, 
pedoman yang mungkin saja relevan untuk diterapkan saat ini.

Berdasarkan hasil observasi beberapa produk seni yang dihasilkan oleh seniman terinspirasi tidak jauh dari lingkungan geografis, misalnya dalam lukisan alam yang menggambarkan bentang lahan, persawahan, hutan, lingkungan pesisir. Kondisi saat mereka melukis adalah mewakili kondisi real saat itu. Ada pula karya yang digunakan sebagai sarana penyampaian pesan yang tak jarang digunakan sebagai inspirasi dalam pengembangan teknologi, konsep dan ilmu pengetahuan, misalnya konsep hari raya Nyepi yang dikaitkan dengan penurunan produksi gas buang berupa gas rumah kaca yang merupakan pemicu pemanasan global .Konsep Tri Hita Karana contohnya konsep Subak juga menjadi contoh dalam konsep pembangunan berkelanjutan.

Dengan wawasan perspektif global mengajarkan kita untuk memandang secara global dan bertindak menggunakan kearifan lokal merupakan pilihan yang tepat. Berdasarkan hal tersebut menjadi dasar yang kuat untuk menelusuri lebih lanjut mengenai hubungan desain produk seni, khususnya seni pewayangan bali yang secara potensial menyimpan berbagai pesan yang dapat digunakan mengatasi permasalahan yang sifatnya global maupun lokal. Seni pewayangan dipilih karena dalam penggambaran seni tersebut dijiwai cerita yang sarat makna dan mengandung pesan/petuah yang terkait dengan lingkungan. Hal inilah yang menjadi gagasan dilakukannya penelitian dengan judul menggali nilai-nilai pelestarian lingkungan geografis pada Beberapa Desain Seni Pewayangan Bali.

Penelitian yang terkait dengan penelitian ini antara lain: 1) Paramadhyaksa, Tanpa Tahun dengan judul penelitian Representasi Gambaran Alam Pada Perwujudan Arsitektur Padmasana di Bali. Penelitian yang beliau laksanakan membahas padmasana melalui sudut pandang bahwa alam semesta disederhanakan menjadi sebuah konsep yakni padmasana. 2) Jana dkk, Tanpa Tahun yang berjudul Kajian Fungsi dan Makna Simbolik Bentuk dan Motif Hias pada Padmasana. Di dalam artikel ini menerangkan unsur yang lebih bersifat estetis dalam kajian pada konsep padmasana. Berdasarkan dua penelitian tersebut maka penelitian yang dilaksanakan memiliki perbedaan tekanan kajian pada fungsionalitas dari konsep padmasana yang pada akhirnya dapat digunakan dalam kehidupan sehari-hari.

Dengan demikian direncanakanlah penelitian untuk dapat menggali nilai-nilai tersebut untuk mengatasi permasalahan terkait pelestarian lingkungan. Adapun metodologi yang dirancang terdiri dari pengumpulan data terkait data produk seni dalam pewayangan Bali. Pewayangan Bali dipilih karena sangat karena sebagai penyampaian pesan yang kaya makna. Setelah data terkumpul maka dilanjutkan identifikasi dan analisis. Analisis yang dilakukan melibatkan analisis hermeneutik. Hasil analisis yang diperoleh adalah dalam salah satu parwa cerita pewayangan yakni Adi Parwa yang mengisahkan adanya pencarian tirta amerta, memperoleh konsep saat ini yang kita kenal sebagai Padmasana. Padmasana ini yang dikenal sebagai bangunan religius oleh umat Hindu menggunakan metode analisis hermeneutic coba diabstraksi kembali secara fungsionalitas untuk menginspirasi tindakan kita agar bijak menggunakan air di alam. Fungsi yang diperoleh proses abstraksi adalah tempat penampungan air yang dapat memperlambat laju hilangnya air secara begitu saja dari permukaan. Tujuan dari penulisan artikel ini adalah untuk mengetahui nilai-nilai dari segi desain seni dalam hubungannya dengan pendeskripsian lingkungan geografis dan mendeskripsikan hubungan timbal balik, 
bahwa dalam karya seni pewayangan Bali terdapat pesan upaya dalam pelestarian lingkungan.

Adapun kajian pustaka yang dianggap relevan terkait dengan tulisan ini yaitu konsep kebudayaan, E. B. Tylor dalam buku "Primitif Culture", menyatakan bahwa kebudayaaan adalah keseluruhan yang kompleks, yang di dalamnya terkandung ilmu pengetahuan yang lain serta kebiasaan yang didapat manusia sebagai anggota masyarakat. $R$. Linton dalam buku "The Cultural Background of Personality", bahwa kebudayaan adalah konfigurasi dari tingkah laku dan hasil laku, yang unsurunsur pembentukan didukung serta diteruskan oleh anggota masyarakat tertentu. C. Klukhohn dan W.H. Kelly menyatakan kebudayaan adalah sebagai hasil tanya jawab dari para ahli antropologi, sejarah, hukum, psychology, yang implisit dan eksplisit, rasional, irasional terdapat pada setiap waktu sebagai pedoman yang potensial bagi tingkah laku manusia (Inrevolzon, 2016). Unsur-Unsur Kebuayaa setelah pengertian kebuayaan maka perlu diketahui unsur-unsur pembentuk kebudayaan. Unsur-unsur yang dimaksud untuk memudahkan mengidentifikasi dan proses observasi dalam penelitian yang akan dilaksanakan. Menurut Koentjaraningrat terdapat 7 (tujuh) unsur kebudayaan yang bersifat universal yaitu : Bahasa, sistem pengetahuan, sistem kemasyarakatan atau organisasi sosial, sistem peralatan hidup atau teknologi, sistem mata pencaharian hidup, sistem religi dan kesenian. Konsep seni juga diperlukan dalam karya tulis ini untuk memaknai arti seni yang dapat dikaitkan dengan lingkungan alam. Seni adalah segala yang berkaitan dengan karya cipta yang dihasilkan oleh unsur rasa. Seni merupakan proses dari manusia, dan oleh karena itu merupakan sinonim dari ilmu. Seni bisa dilihat dalam intisari ekspresi dari kreatifitas manusia. Seni sangat sulit untuk dijelaskan dan juga sulit dinilai, bahwa masing-masing individu artis memilih sendiri peraturan dan parameter yang menuntunnya atau kerjanya, masih bisa dikatakan bahwa seni adalah proses dan produk dari memilih medium, dan suatu set peraturan untuk penggunaan medium itu, dan suatu set nilai-nilai yang menentukan apa yang pantas dikirimkan dengan ekspresi lewat medium itu, untuk menyampaikan baik kepercayaan, gagasan, sensasi, atau perasaan dengan cara se-efektif mungkin untuk medium itu.

Sekalipun demikian, banyak seniman mendapat pengaruh dari orang lain masa lalu, dan juga beberapa garis pedoman sudah muncul untuk mengungkap gagasan tertentu lewat simbolisme dan bentuk (Setiawan, 2011). Dalam seni terbagi menjadi beberapa cabang ilmu kesenian yang dapat dikelompokkan menjadi sastra dan seni rupa.

Sastra merupakan kata serapan dari bahasa Sanskerta, śāstra, yang berarti "teks yang mengandung instruksi" atau "pedoman", dari kata dasar śās- yang berarti "instruksi" atau "ajaran". Dalam bahasa Indonesia kata ini biasa digunakan untuk merujuk kepada "kesusastraan" atau sebuah jenis tulisan yang memiliki arti atau keindahan tertentu. Dalam seni sastra sendiri terdapat beberapa sub cabang kesenian, antara lain: cerpen, novel, pantun, peribahasa, sandiwara, syair, wiracarita.

Seni Rupa adalah cabang seni yang membentuk karya seni dengan media yang bisa ditangkap mata dan dirasakan dengan rabaan. Kesan ini diciptakan dengan mengolah konsep garis, bidang, bentuk, volume, warna, tekstur, dan pencahayaan dengan acuan estetika. Seni rupa dibedakan ke dalam tiga kategori, yaitu seni rupa murni atau seni murni, kriya, dan desain. Seni rupa murni mengacu kepada karya-karya yang 
hanya untuk tujuan pemuasan eksresi pribadi, sementara kriya dan desain lebih menitikberatkan fungsi dan kemudahan produksi. Keberadaan sastra dan seni rupa khususnya yang terkait dengan kebudayaan dan kearifan lokal Hindu Bali akan dijadikan pedoman bagi penulis untuk menggali nilai-nilai pada seni tersebut terutama yang berkaitan dengan lingkungan alam.

Dalam penelitian ini akan difokuskan pada tema cerita mahabrata dan Ramayana. Berikut adalah salah satu penggambaran seni lukis cerita pewayangan yang dibuat oleh maestro Nyoman Gunarsa seperti terlihat pada Gambar 1.

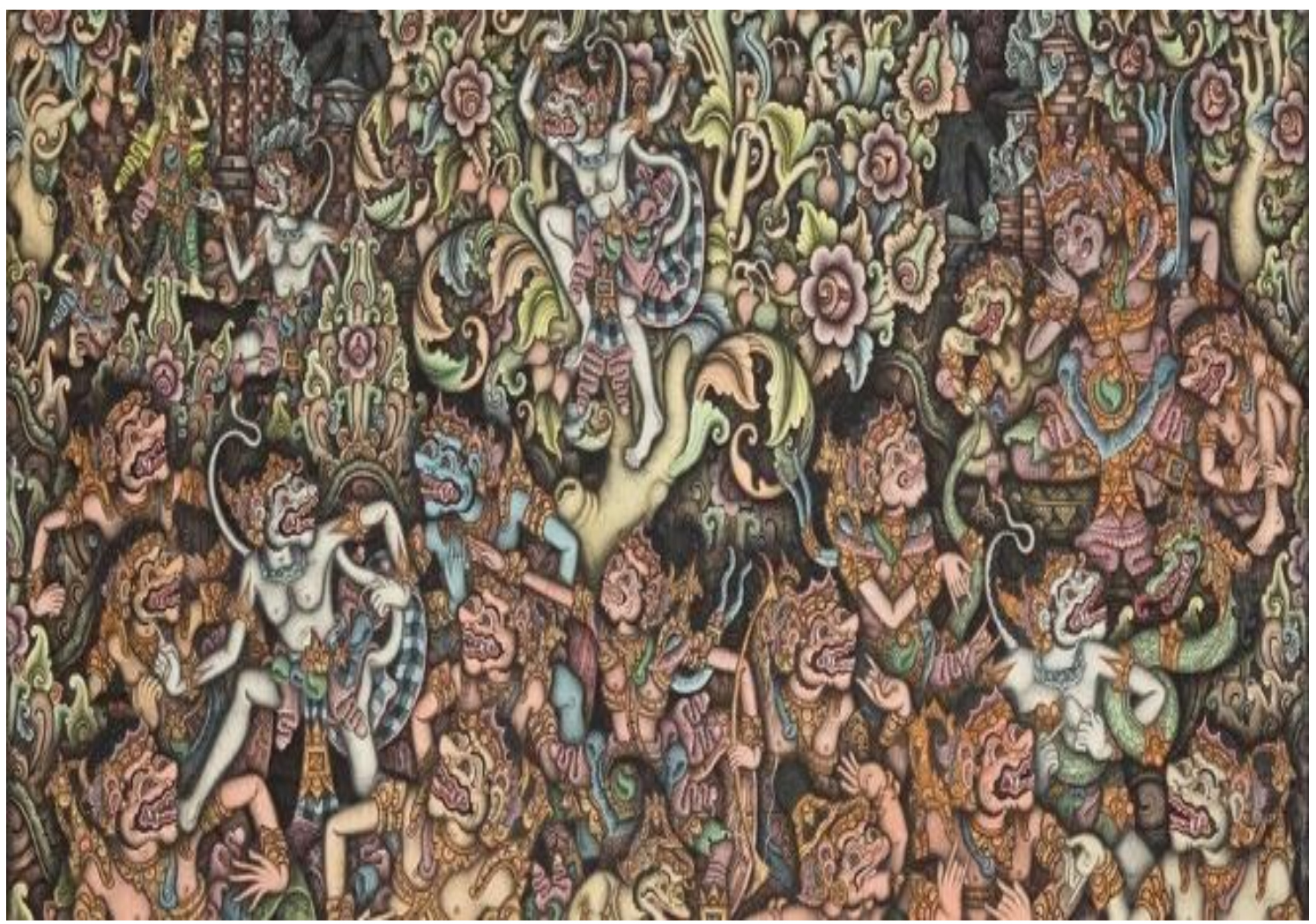

Gambar 1. Lukisan Pewayangan Klasik Bali

Unsur- unsur kebudayaan kearifan lokal Bali kemudian dihubungkan dengan pelestarian lingkungan hidup (lingkungan Geografis). Dalam Undang-Undang Nomor 23 Tahun 1997 tentang Pengelolaan Lingkungan Hidup menyebutkan pengertian lingkungan adalah kesatuan ruang dengan semua benda, daya, keadaan dan makhluk hidup termasuk manusia dan prilakunya yang mempengaruhi kelangsungan perikehidupan dan kesejahteraan manusia serta makhluk hidup lain (Pasal 1 ayat 1 ).

$$
\text { Menurut Supardi (2003), }
$$

lingkungan atau sering juga disebut lingkungan hidup adalah jumlah semua benda hidup dan benda mati serta seluruh kondisi yang ada di dalam ruang yang kita tempati.

\section{Metode}

Langkah-langkah penelitian yang akan dilaksanakan secara general terdiri dari proses perencanaan yang dijabarkan melalui alur penelitian, dilanjutkan pengumpulan, identifikasi dan analisis data.

Rancangan penelitian yang akan dilaksanakan mengikuti alur yang direncanakan seperti terlihat pada Gambar 2. 


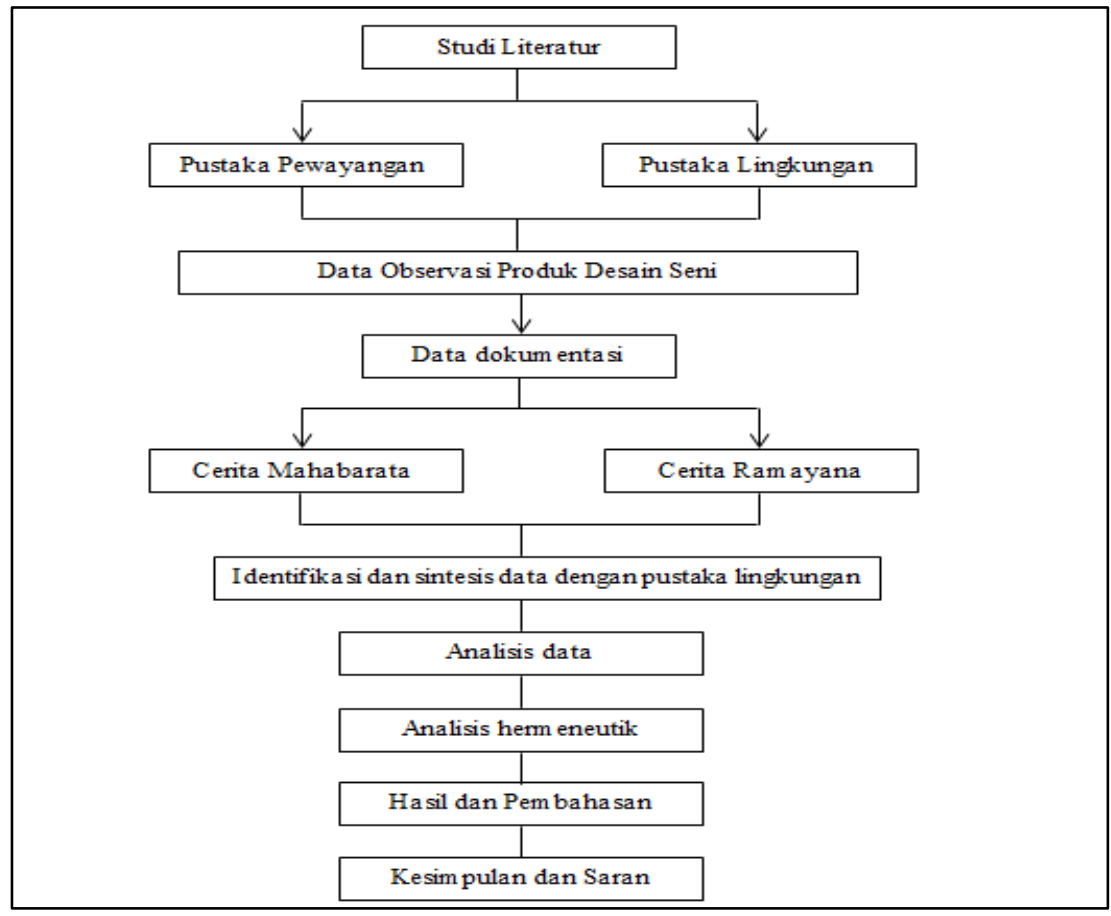

Gambar 2. Alur Penelitian

Data yang digunakan dalam penelitian adalah data yang berasal dari pustaka pewayangan, maka teknik pengumpulan data yang dipilih adalah dokumentasi maupun observasi. Beberapa sumber data dapat diproleh pula melalui hasil karya seni wayang bali yang terdokumentasi dalam cerita melalui teks maka dapat digunakan sebagai pedoman dalam memahami keutuhan dari produk seni pewayangan dalam menyampaikan pesan. Beberapa yang dalam desain pertunjukan, ukiran/lukisan yang berseri dapat diobservasi untuk mengkaji secara mendalam makna yang terkandung didalamnya.

Beberapa data yang dikumpulkan dari hasil observasi dan dokumentasi maka dilakukan proses identifikasi dengan berpedoman pada konsep lingkungan dan unsur-unsur dalam lingkungan. Unsurunsur yang dimaksud terdiri dari abiotik, biotik dan kultur. Keterkaitan ketiga unsur tersebut menghasilkan kondisi lingkungan, serta peran manusia dalam pelestariannya. Gamabr 3 adalah penggambaran hubungan ketiga komponen tersebut.

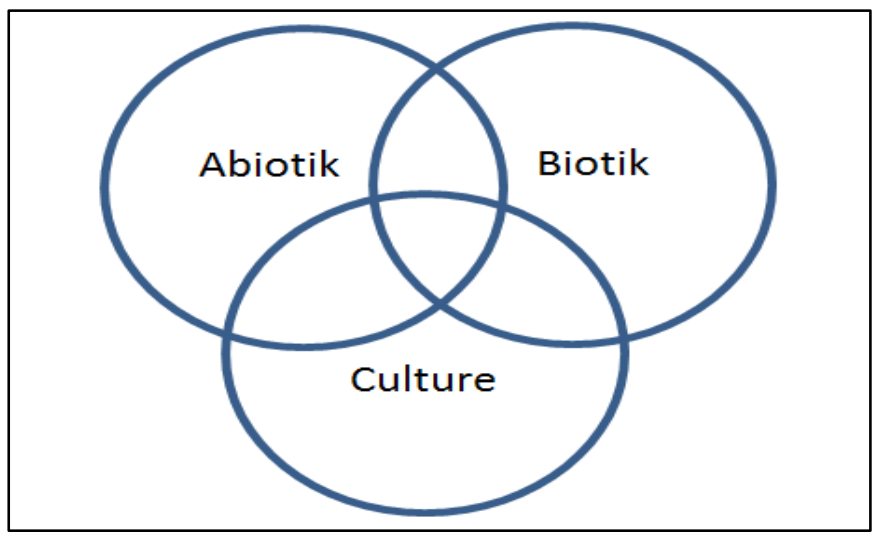

Gambar 3. Hubungan antar Unsur Lingkungan 
Lingkungan yang dimaksud akan dihubungkan dengan lingkungan geografis yang teriri atas bagian-bagiannya, seperti yang dijelaskan dalam kajian pustaka untuk memudahkan dalam melakukan proses identifikasi.

Data yang telah diidentifikasi akan dilanjutkan dengan analisis data. Analisis yang dimaksud adalah melalui hasil identifikasi produk seni dalam pewayangan bali, maka dapat dikenali serta dicari hubungannya antar satu bagian dengan bagian lainnya. Namun dalam penelitian ini akan melibatkan metode lain untuk memahami karya seni tersebut yakni hermeneutik. Analisis Hermeneutik dipilih mempertimbangkan kedalaman hasil analisis yang memungkinkan pula melibatkan ilmu lain yang berkaitan di dalamnya misalnya psikologi, sosiologi, sejarah dan lainlainnya. Dengan demikian maka produk seni wayang yang akan dikaji dapat dilihat kaitannya dengan ilmu lain misalnya lingkungan atau geografis yang merupakan fokus dari penelitian ini. Gambar 4 adalah gambaran sistematika metode herneneutik.

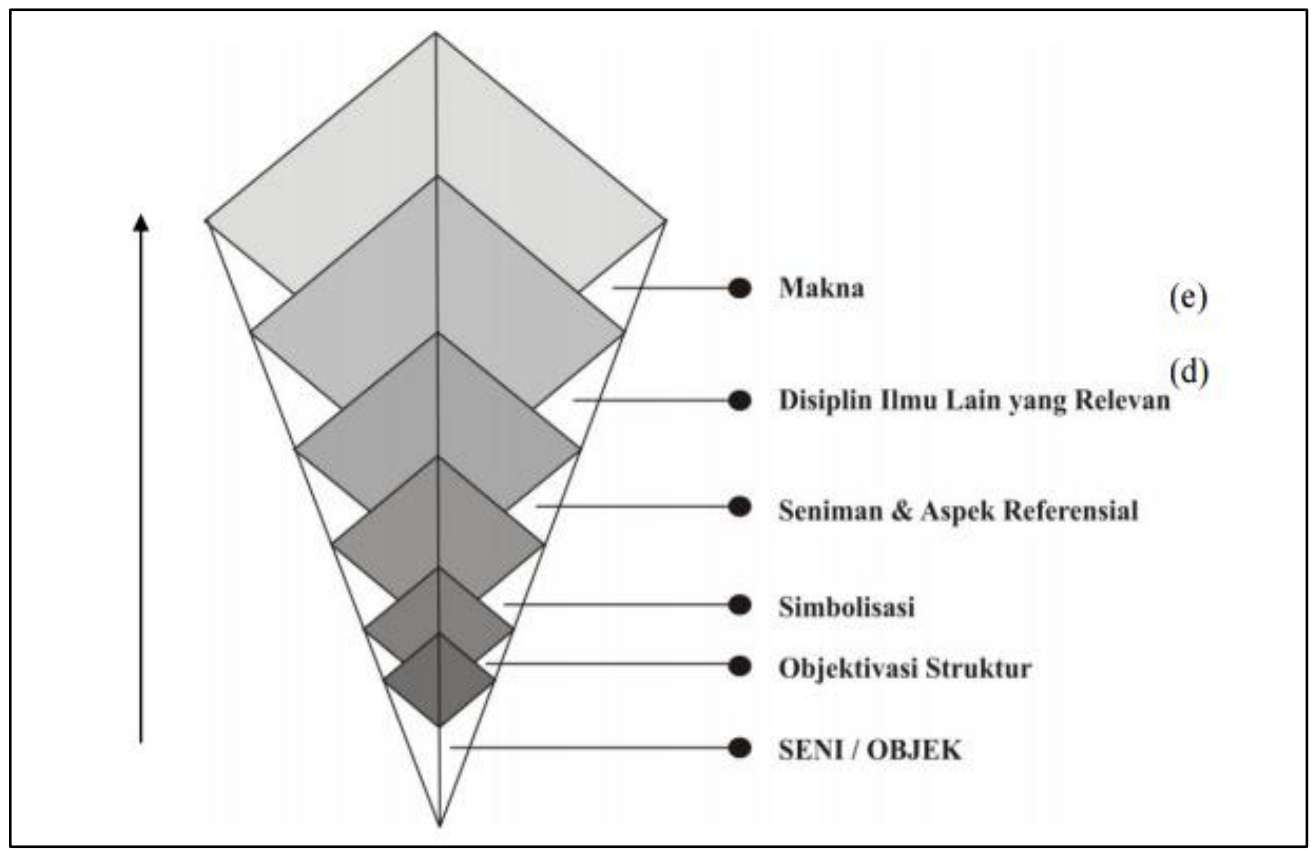

Gambar 4. Metode Pengkajian Hermeneutik

Sumber : Saidi, 2008

Menurut Saidi (2008) sistematika analisis tersebut dapat dijabarkan ke dalam langkah - langkah sebagai berikut. Pertama, karya seni ditempatkan sebagai objek yang diteliti sekaligus sebagai subjek atau pusat yang otonom. Karya seni diposisikan sebagai fakta ontologi. Selanjutnya, karya seni sebagai fakta ontologi dipahami dengan cara mengobjektivasi strukturnya. Di sini analisis struktural menempati posisi penting. Pada tahap berikutnya, pemahaman semakin meluas ketika masuk pada lapis simbolisasi. Hal ini terjadi sebab di sini tafsir telah melampaui batas struktur. Kode-kode simbolik yang ditafsirkan tentu saja membutuhkan hal-hal yang bersifat referensial menyangkut proses kreatif seniman dan faktor-faktor yang berkaitan dengannya. Kode simbolik yang dipancarkan teks dan dikaitkan dengan berbagai persoalan di luar dirinya menuntut disiplin ilmu lain untuk melengkapi tafsir. 


\section{Hasil dan Pembahasan}

Beberapa bahan telah coba untuk dipahami yang menyusun bagian perbagian dari susunan cerita pewayangan. Penulis memulai dari mahabarata pada bagian pertama/awal dari 18 Parwa yang didesain sebagai keutuhan cerita tersebut yang dikenal dengan Asta Dasa Parwa. Bagian pertama yakni bernama Adi Parwa yang materinya terdiri dari beberapa kisah yakni, pemutaran mandaragiri, kisah para leluhur pandawa dan korawa, kisah masa kanak-kanak pandawa dan korawa dan beberapa cerita lain. Penulis memulai dari bagian pertama dari kisah ini yakni pemutaran mandara giri yang secara sekilas diketahui sebagai upaya pencarian tirta amerta oleh para dewa dan raksasa. Pemutaran tersebut dilakukan dengan bantuan Kurma Awatara sebagai penjelmaan Dewa Wisnu ke Dunia, Gunung Mandara Giri serta Naga Basuki untuk memutar gunung tersebut.

$$
\text { Dalam cerita tersebut }
$$

meninggalkan karya yang disucikan saat ini yang juga syarat dengan makna serta nilai seni yakni Padmasana. Berikut Penjelasan mengenai Padmasana. Secara lebih spesifik penelitian ini membahas terkait dengan bangunan suci padmasana merupakan representasi alam semesta. Dengan penelitian ini terdapat benang merah untuk dapat dikaitkan dengan mitologi bagaimana dihasilkannya air suci. Padmasana diartikan sebagai sebuah tempat duduk atau singgasana berbentuk teratai merah bagi Ida Sang Hyang Widhi atau Tuhan. Dalam literaturliteratur berbahasa Inggris, padmasana sering kali disebutkan sebagai" the Balinese empty lotus throne-shrine" atau bangunan suci Hindu-Bali yang memiliki sebentuk kursi singgasana teratai yang kosong di bagian puncaknya (Forbes, 2007: 125 dalam Paramadhyaksa, Tanpa Tahun).
Perwujudan bangunan ini juga memiliki tiga buah tingkatan utama sesuai konsepsi tri angga dalam seni arsitektur tradisional Bali. Ketiga tingkatan tersebut yaitu tingkatan kaki bangunan (tepas), tingkatan badan bangunan (batur), dan tingkatan kepala atau puncak bangunan (sari) (Suendi, 2005: 65 dalam Paramadhyaksa, Tanpa Tahun). Pada ketiga bagian utama tersebut terdapat berbagai figur tiga dimensi, ornamen, dan relief dekoratif yang terbuat dari material bata merah, batu padas, atau batu-batu alam. Padmasana merupakan bentuk bangunan Padma yang paling utama. Bangunan Padma lainnya disebut dengan nama padmasari dan padmacapah. Bangunan suci jenis padmasari tidak dilengkapi dengan ornamen bedawang nala di dasar bangunannya. Padmacapah merupakan bangunan suci kelompok Padma paling rendah tingkat kesuciannya yang difungsikan untuk penghormatan berbagai kekuatan spirit alam yang lebih rendah.

Mempertimbangkan permasalahan lingkungan yang terjadi pada era ini, tidak hanya menyangkut lingkungan semata tapi juga gaya hidup manusia yang telah berkembang juga penting artinya dalam memberikan pengaruh terhadap kondisi lingkungan saat ini.

Hasil abstraksi yang dapat dilakukan adalah menggunakan prinsip pada bagian metodologi penelitian dalam metode khusus yakni hermeneutika. Pada rancangan tersebut maka dapat dijabarkan beberapa hal berikut.

Padmasana sebagai representasi alam semesta menggunakan simbolis yang dibentuk berdasarkan daya imajinasi dari masyarakat local (masyarakat Hindu Bali). Hal tersebut sangan unik, yang dimana konsep buana agung atau alam yang dipadatkan, disarikan ke dalam bentuk/perwujudan yang lebih sederhana. Pada tahap awal metode hermeneutika kita telah dapatkan penjelasan secara 
ontology melalui sumber-sumber penelitian lain yang diantaranya telah pula masuk ke bagian yang ke tiga terkait dengan langkah penafsiran yang melampaui struktur. Dalam penelitian tersebut terdapat penafsiran dengan mengambil kesamaan-kesamaan serta memberikan hubungan melalui kajian sebelumnya.

Pada langkah berikutnya dilakukan proses kreatif dengan tidak hanya menafsirkan secara harfiah semata tapi terkait pula dengan fungsional dari objek yang dimaksud. Disamping itu fungsional yang dimaksud dapat menjadi bagian dari alam untuk meremajakan, memperbaiki dirinya sendiri. Konsep tersebut dituangkan ke dalam penjelasan berikut. Jika padmasana dalam penjelasan di atas dibagi menjadi 3 bagian penting yakni bagian tepas/bawah kemudian bagian batur/tengah dan sari/atas. Pada bagian bawah terdapat bentuk kura-kura dan naga yang dinyatakan sebagai symbol magma dan air.

Dari hal tersebut dapat ditarik penafsiran bahwa magma membeku menjadi tanah dan batuan pada kerak bumi kemudian dapat dilaui air. Kondisi seperti itu dapat kita temukan pada aquifer yakni tempat dimana air tanah bias kita temukan. Denagn demikian aquifer yang fungsinya menyimpan dan meloloskan air tanah dapat dijadikan dasar sebagai pembuatan projek water storage ini. Kemudian pada bagian berikutnya terdapat kepala gajah pada masingmasing sudut yang dalam imajinasi menggunakan belalai sebagai tempat jalannya air. Kemudian menggunakan organ dalamnya untuk menyaring air. Air yang masuk akan disimpan dalam tangki dalm bentuk badan/punggung kura-kura. Kemuadian output untuk menggunakan air tersebut dapat melalui mulut 2 naga serta bagian puncak. Pada bagian puncak khusunya air tidak akan bias diambil secara mudah. Hal tersebut disebabkan gaya gravitasi. Pada bagian kedua diibaratkan gunung. Kemudian gunung memiliki pipa kepundan tempat jalannya magma. Jalan magma tersebut dapat digunakan sebagai jalan air dengan menaikkannya menggunakan naga untuk menarik dan memutar gunung. Penarik dari 2 sisi pada masing-masing ujung naga. Berdasarkan hal tersebut tidak mendapatkan solusi kemudian cakra dewa Wisnu membantu menginisiasikan tercetusnya ide menggunakan motor untuk menaikan air ke puncak. Gambar 5 merupakan representasi dari model tersebut.

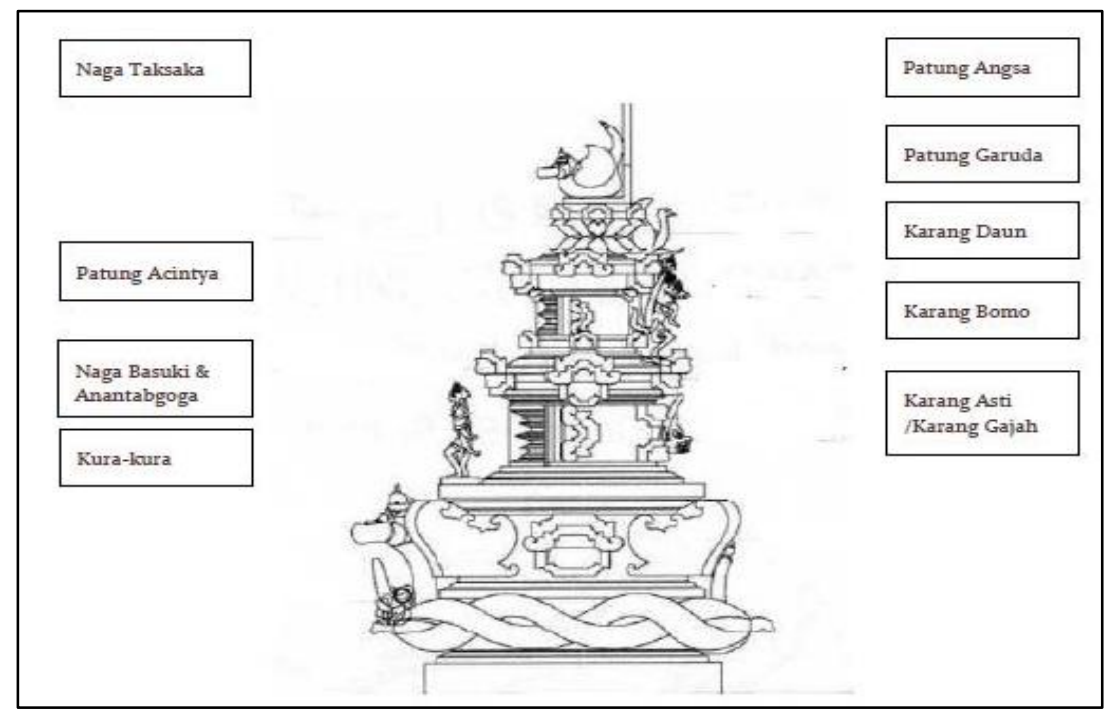

Gambar 5. Representasi Padmasana 
Berdasarkan konsep padmasana secara riil yang kita temukan dalam sehari-hari, membantu mengabstraksi konsep yang baru terkait dengan water storage seperti terlihat pada Gambar 6.

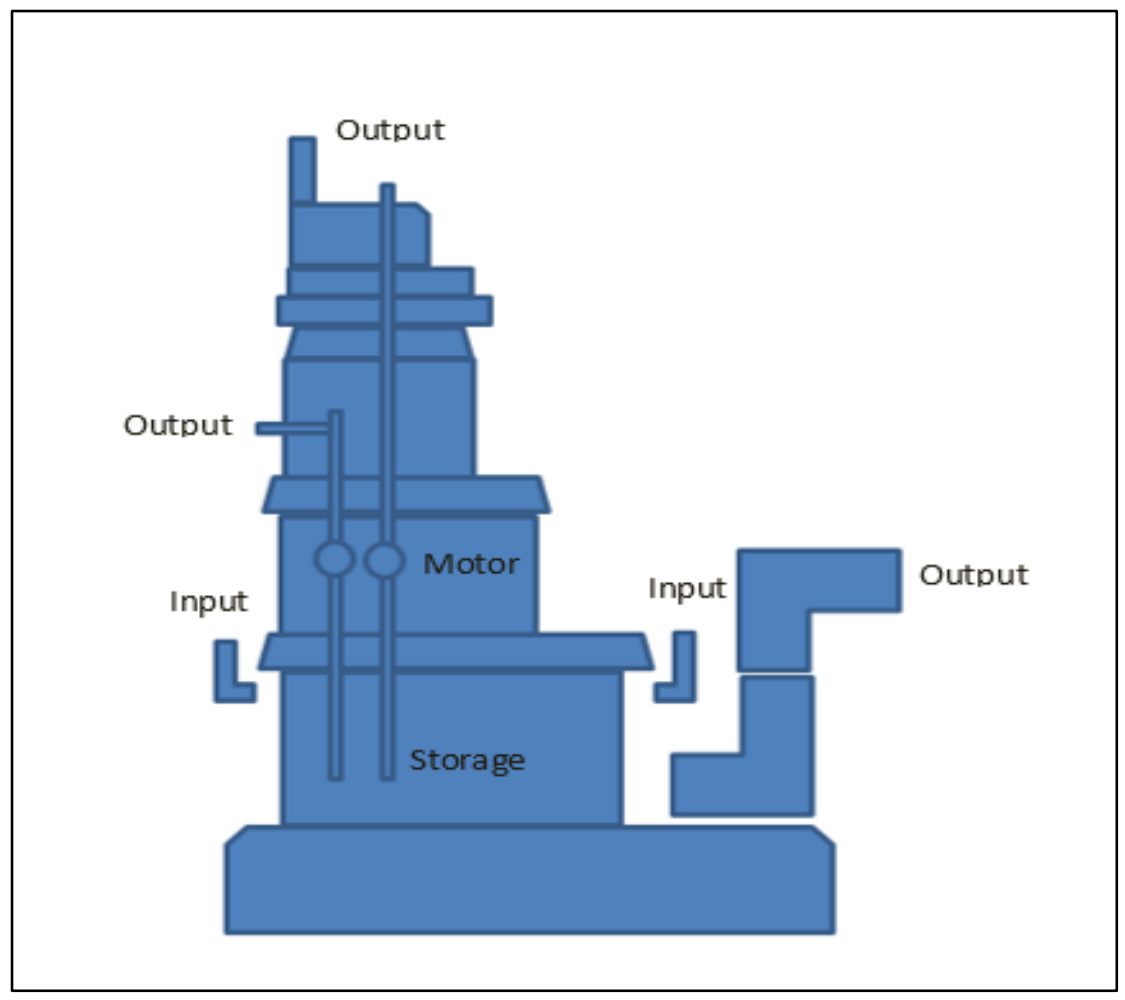

Gambar 6. Abstraksi Konsep Water Storage dari Padmasana

\section{Kesimpulan}

Adapun kesimpulan yang dapat diambil dari penelitian tersebut adalah nilai pelestarian lingkungan geografis yang dapat diambil dari desain pewayangan adalah bagaimana cara memanfaatkan air yang tersebar di alam secara bijak. Konsep padmasana yang diyakini selama ini sebagai konsep yang mengandung nilai religious dapat dimaknai secara ilmiah pula melalui ulasan maupun analisis teknologi di dalamnya. Dengan dilakukan penelitian ini untuk selanjutnya direncanakan penelitian pembuatan prototype penampungan air untuk memenuhi kebutuhan masyarakat ketika menghadapi musim kemarau.

\section{Ucapan Terimakasih}

Terimakasih diucapkan kepada Tim MKG Fakultas Hukum dan IImu Sosial Undiksha
Singaraja yang telah memberikan kesempatan untuk diterbitkannya karya tulis ini. Diucapkan juga terimakasih kepada STMIK STIKOM Indonesia terutama pihak LPPM dan rekan-rekan yang telah memberikan dukungan materi dan non materiuntuk terwujudnya karya ini.

\section{Daftar Pustaka}

Inrevolzon,.2016. Kebudayaan dan Peradaban. Jurusan Sejarah dan Kebudayaan Islam Fakultas Adab dan Humaniora IAIN Raden Fatah Palembang.

Jana, dkk, Tanpa Tahun. Kajian Fungsi dan Makna Simbolik Bentuk dan Motif Hias pada Padmasana. Jurusan/Prodi Kriya Seni FSRD ISI Denpasar. 
Koentjaraningrat. 2009. Pengantar IImu Antropologi. Jakarta: Rineka Cipta.

Paramadhyaksa, I Nyoman Widya. Representasi Gambaran Alam Pada Perwujudan Arsitektur Padmasana di Bali. Tanpa Tahun. Jurusan Arsitektur, Fakultas Teknik, Universitas Udayana

Saidi, Acep Iwan.2008. Hermeneutika, Sebuah Cara untuk Memahami Teks. Jurnal Sosioteknologi Edisi 13.ITB.

Setiawan, Heru. 2011. dalam http://ejournal.uajy.ac.id/2174/3/2TA112 10.pdf diakses tanggal 18 Juni 2018.

Supardi, Imam. 2003. Lingkungan Hidup dan Kelestariannya. Bandung : PT Alumni. (http://www.e-jurnal.com/2013/10/unsurunsur-kebudayaan.html diakses pada tanggal 4 Juni 2018 11.55).

(https://asisbuton.files.wordpress.com/200 9/03/id28-nilai-norma.pdf) diakses tanggal 18 Juni 2018.

Lauthfi.wordpress.com/2008/08/21/definisi -desain-grafis/ (lauthfi, 2008) diakses tanggal 18 Juni 2018. Undang-Undang Nomor 23 Tahun 1997. 